St. Anne's College, Oxford, and Dr. Audrey Richards, Director of the East African Institute of Social and Economic Research.

\title{
Chura na Nyoka (The Toad and the Snake)
}

THE Bulletin of C.E.P.S.I. (Centre des Problèmes Sociaux Indigènes) has published as a supplement to its issue of November 1953 the text and musical score of a play devised by Joseph Kiwele, and performed in Elisabethville in June 1952. The play is based on a traditional Kongo story and the arrangement includes dances, songs, and dialogue-the songs, composed by Kiwele, include traditional African melodies.

Kiwele, who was born in the village of Mpala, Lake Tanganyika, showed evidence of musical ability from childhood and received some training in European liturgical music while still at school. He came to Elisabethville as assistant to Dom Anschaire Lamoral, the founder of the well-known African choir 'Chorale à la Croix de cuivre'; Kiwele conceived the idea of training the choir to sing African music and wrote several collections of songs based on traditional airs. At this time he composed the work which made him widely known-his Missa Katanga, which was first sung at the Mission St. Jean, then at the Cathedral in Elisabethville and more recently in Antwerp. Kiwele then turned his attention to the composition of musical plays incorporating traditional songs and dances, of which Chura na Nyoka is the best known, but he returned to liturgical music, and on Christmas Eve I 952 his Missa ya Jubile was sung at the Mission St. Jean. This mass, dedicated to the Vicar Apostolic of Katanga in honour of the fiftieth year of his priesthood, marked a new level of musical achievement. Profoundly Christian in spirit and deeply responsive to the dramatic motives of the Mass, it is African not European in quality; drums and xylophones are used to accompany and reinforce the melodic themes, and the distinctive rhythms of African music form the framework of the whole composition. Dom Thomas More Weitz, O.S.B., in his introduction to the text of Chura na Nyoka, writes of the Missa ya Jubile: ' Cette très belle Messe . . . est vraiment un nouveau chef-d'œuvre de musique authentiquement religieuse. . . . Joseph Kiwele a indéniablement enrichi la musique bantoue. En effet, il parvient à exposer un thème en le répétant dans des rythmes différents, parfois usant du renversement, créant de la sorte un grand mouvement grâce auquel ses compositions . . forment un tout substantiel. Avant Kiwele, cela n'existait pas; au contraire, le thème, sauf dans les pièces courtes, était rapidement épuisé. . . . Joseph Kiwele . . . réussit à prouver que la musique bantoue mérite d'occuper une place dans la musique chorale, tant religieuse que profane.'

\section{A l'Institut d'Etudes Centrafricaines}

LE Club des Chercheurs de l'Institut d'Études Centrafricaines a organisé à Brazzaville, au Club-House de l'Institut, sa première manifestation publique. C'est M. Pepper, musicologue de l'I.E.C. et Président du Club, qui assuma la responsabilité de cette initiative en faisant entendre une série des enregistrements musicaux qu'il s'attache depuis plusieurs années à recueillir et à étudier.

Le Professeur Trochain, Directeur de l'Institut d'Études Centrafricaines, présenta la personnalité de M. Pepper, et l'ensemble de ses travaux depuis l'étude des langages tambourinés qui lui fut suggérée par le Gouverneur Général Éboué, jusqu'à l'étude élargie des langages musicaux et à 'l'aperception' du système fondamental de l'harmonie africaine.:

Herbert Pepper est en train de livrer, à l'ethnologie africaine entendue de façon la plus large, un enseignement fondamental. Ses derniers travaux prennent figure de découvertes; jamais peut-être le symbolisme bantou compris non plus de façon limitative et notamment figurative, mais entendu comme un vaste système vital, jamais ce symbolisme n'aura été 